\title{
Study on the production of VAR electrodes from Zircaloy turning lathe chips
}

\author{
Mucsi, C. S. ${ }^{1 *}$; Reis, L. A. M. ${ }^{1}$; Rossi, J. L. ${ }^{1}$ \\ 1. Instituto de Pesquisas Energéticas e Nucleares, IPEN - CNEN, São Paulo, SP, Brazil.
}

*e-mail: csmucsi@ipen.br

\begin{abstract}
Resumo
Cavacos de Zircaloy 4 são produzidos em larga escala durante a usinagem de tubos Zircaloy 4 para peças do elemento combustível de reatores PWR. Atualmente Zircaloy 4 é uma liga de zircônio importada para o Brasil e sua usinagem gera cavacos que são um desafio para a indústria da reciclagem. Esse trabalho apresenta o primeiro passo do processo de reciclagem e os resultados para a procura de uma maneira eficiente de limpeza, controle de qualidade e fabricação do eletrodo no VAR (Vacuum Arc Remelting). O processo começa com a lavagem do óleo de corte e é seguido pela prensagem dos cavacos limpos. A primeira avaliação do processo foi feita por testes de fluorescência de raio-X com o intuito de definir a qualidade dos cavacos. Os resultados indicaram que é preciso incluir a etapa de separação magnética no processo para extração de liga ferrosa presente nos cavacos. $O$ processo de prensagem dos cavacos produziu um eletrodo de $1 \mathrm{~kg}$ para ser fundido em um protótipo de forno VAR no CCTM. Os autores também concluem que as amostras obtidas da indústria de elementos combustíveis são de cavacos secundários e sugerem a eles um procedimento de estocagem de cavacos.
\end{abstract}

\begin{abstract}
Zircaloy 4 chips are produced in large quantities during the machining of Zircaloy 4 rods for the PWR fuel elements parts. Currently Zircaloy 4 is a zirconium alloy imported into Brazil and the machining chips scraps poses a challenge to the recycling industry. This paper presents the first step on the recycling processes and the results for the search of an efficient way on the cleaning, quality control and Vacuum Arc Remelting (VAR) electrode fabrication. The process starts with cutting oil washout and is followed by the die pressing of the clean chips. Process evaluation was first made by means the X-ray fluorescence tests in order to define the quality of the scraps. Results indicates the need of the inclusion of a magnetic separation step in the process to withdraw the ferrous alloy present in the scraps. The die pressing of the scraps yield process adequate $1 \mathrm{~kg}$ electrodes to be melted in the CCTM prototype scale VAR furnace. The authors also conclude that the samples obtained from the fuel element industry are secondary scraps and suggest them a procedure for the scrap stocking.
\end{abstract}

Keywords: Vacuum, Zircaloy, VAR and Electric Arc Melting.

\section{Introduction}

The nuclear fuel used in PWR power reactors is typically composed of uranium dioxide pellets $\left(\mathrm{UO}_{2}\right)$, packaged in tubes made of zirconium alloys, called casing or cladding. These tubes form the fuel rod are, arranged in sets of $14 \times 14$ to $17 \times 17$ tubes forming the fuel element, as can be seen in Figure 1. Zirconium alloys commonly used in rods and fuel elements are known as Zircaloys and are adequate for the use in the power generating Water reactors due to its ability to resist to corrosion in the high temperature water and transparency to thermal neutrons [1]. The machining of these tubes generate chips contaminated with machining oil and cutting fluid. Zircaloy 4 chips are produced in large quantities during the machining of Zircaloy 4 rods for the PWR fuel elements parts. Actually, Zircaloy 4 is a zirconium alloy imported into Brazil and the machining chips scraps poses a challenge to the recycling industry. This paper presents the first steps on the recycling processes and the results for the search of an efficient way on the cleaning, quality control and Vacuum Arc Remelting (VAR) electrode fabrication. The process starts with the cutting fluid washout and is followed by the die pressing of the clean chips. Process evaluation was first made by means the X-ray fluorescence tests in order to define the quality of the scraps. Results indicates the need of the inclusion of a magnetic separation step in the process to remove the ferrous alloy present in the 
scraps. The die pressing of the scraps yield process adequate $1 \mathrm{~kg}$ electrodes to be melted in the CCTM prototype scale VAR furnace [2].

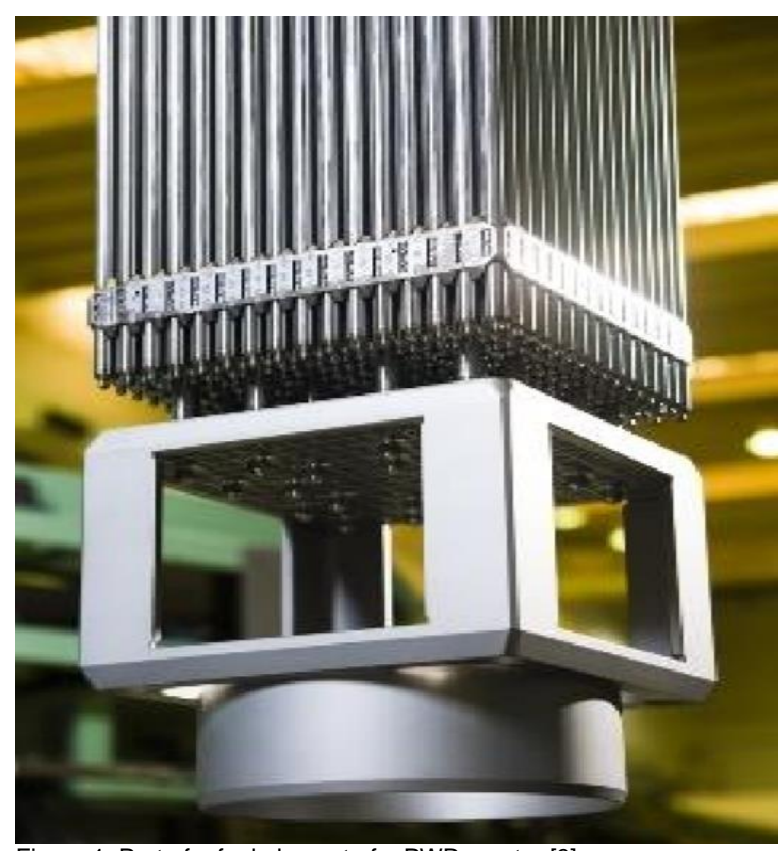

Figure 1: Part of a fuel element of a PWR reactor [3].

\section{Experimental}

Small amounts of the original machined material were randomly collected in the delivery drums and then pressed in a $20 \mathrm{~mm}$ diameter mold. The pellets were then subjected to X-ray fluorescence analysis as a way to determine the presence of impurities, as a quality control procedure [4].

Three different tests were performed in order to evaluate different routes for the cleaning of the Zircaloy 4 scraps in $1 \mathrm{~kg}$ batches:

\section{Test process:}

1.1 Use of organic solvent for the dissolution of the oily fluid followed by drying. In this route the amount of Zircaloy 4 scraps weighted $100 \mathrm{~g}$;

\section{Cleaning process \#1:}

2.1 Immersion an amount of $1 \mathrm{~kg}$ of Zircaloy 4 scraps in a clean water drum;

2.2 Dissolution of oily fluid in an industrial alkaline solvent with a $\mathrm{NaOH}$ content;

2.3 Rinsing by immersion in clean water and;

2.4 Drying.

3. Cleaning process \#2:

3.1 Immersion an amount of $1 \mathrm{~kg}$ of Zircaloy 4 scraps in a clean water drum;

3.2 Dissolution of oily fluid in an industrial alkaline solvent with a $\mathrm{NaOH}$ content;
3.3 Washing with high pressure (1000 psi) water jet and;

3.4 Drying.

The magnetic field of a magnetic rod was applied to the loose cleaned scraps, in order to evaluate the presence of magnetic (ferritic or martensitic) ferrous alloys that could be present in the scraps.

As for the original material, small amounts of scraps from each cleaning processes were pressed in a $20 \mathrm{~mm}$ diameter mold in order to be vacuum arc melted and then analyzed by X-ray fluorescence for quality control purposes.

Clean Zircaloy 4 scraps were then pressed in a $400 \mathrm{~mm}$ long $40 \mathrm{~mm}$ square section die, specially produced for the purpose of producing VAR (Vacuum Arc Remelting) furnace electrodes, as shown in Figure 2.

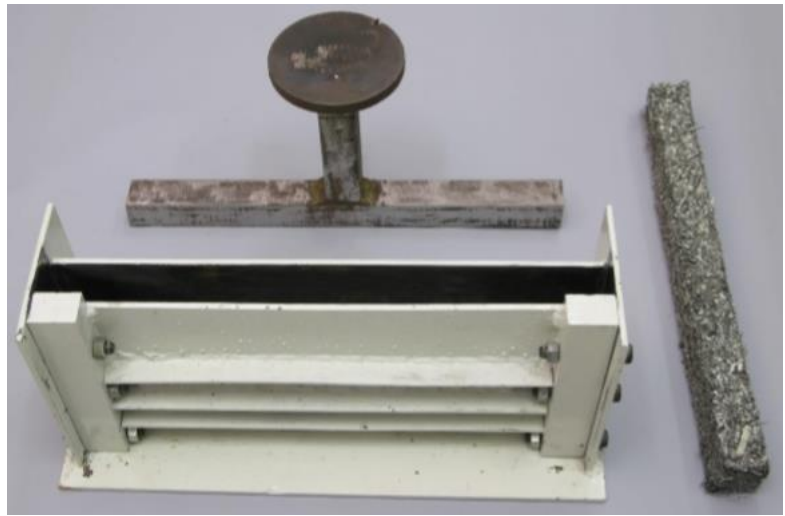

Figure 2: Press die set and the resulting electrode.

\section{Results and Discussion}

X-ray fluorescence of the original material indicates the presence of a ferrous steel alloy, Al-Si other than the original Zircaloy 4 alloy, the same for the pressed control pellets. Magnetic separation shows nonhomogeneous results but there were regions within the original drums exhibiting a concentration of magnetic materials as high as $17 \%$. The fact that the material is a mixture of different alloys is fundamental to the development of the cleaning process and makes the material a secondary scrap. This result indicates the need of a careful collection and storing of the scraps during the lathe process to avoid such impurities to be added to the alloy during the scraps melting. On the cleaning, organic solvents are very easy to use but the huge amounts necessary to clean industrial quantities of scraps make its use not only very expensive but environmentally dangerous, so this route was promptly abandoned and considered as a test only. Cleaning processes \#1 and \#2 differ only in the final rinsing. The first step of both process uses 20 liters of water per $1 \mathrm{~kg}$ of scraps due to the experimental arrangement; this amount of water can be diminished with the use of 
bigger drums with adequate shapes for the first water dissolution. The alkaline dissolution consumes no expressive amount of water since the solution dissolves the oily fluid and can be reused on and on. The rinsing step places a great difference between the two processes. Process \#1 takes approximately 80 liters of water to rinse the scraps to a clean surface. In process \#2 the high-speed water jet easily removes the dirty alkaline solution from the scraps, consuming 10 liters of water per $1 \mathrm{~kg}$ of scraps.

Pressing the scraps in a special die results in $1 \mathrm{~kg}$ VAR electrodes with approximately $20 \%$ the bulk density of the Zircaloy 4 alloy. This electrode density makes the electrode very sensitive to lateral loads and therefore it must be stored carefully. Otherwise, during melting the electrode is only subjected to axial loads due to its own weight. This fact indicates that it is a viable electrodemanufacturing route for the laboratory VAR furnace [5, 6]. In Figure 3, it is shown a clean amount of Zircaloy 4 scraps and the VAR electrode.

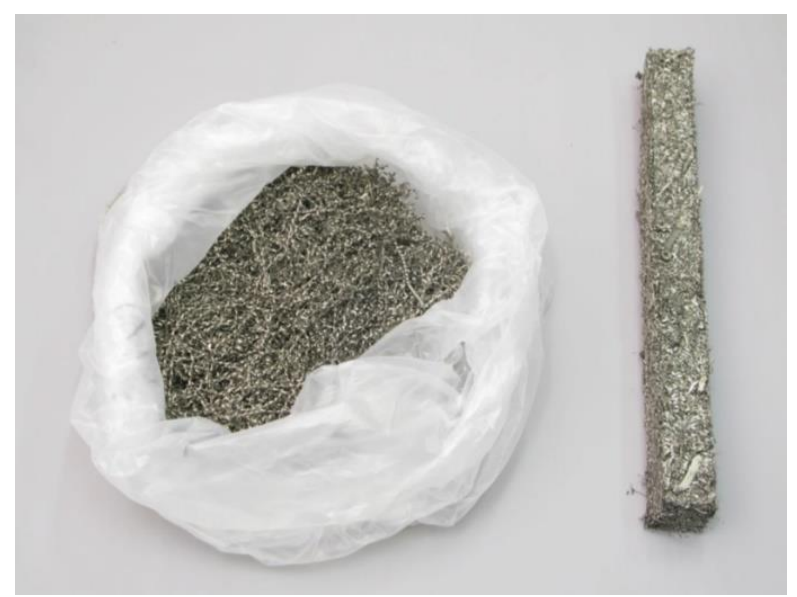

Figure 3: Clean scraps and the produced electrode.

\section{Conclusion}

The original scraps presented a contamination with ferrous and aluminum alloys. This contamination turns the scraps to the secondary type making its recycling difficult and requiring extra process steps and energy consumption. This problem can be overtaken by careful separation and storing of the material during and after production. It would benefit the final material after VAR furnace melting.

The laboratory scale study of the process for the Zircaloy 4 scraps cleaning was adequate for the evaluation of the cleaning process variables aiming the melting in the laboratory VAR furnace. The use of highpressure water jet for the rinsing was fundamental for the diminution of the water consumption from 100 liters per $1 \mathrm{~kg}$ of scraps to 30 liters per $\mathrm{kg}$ of scraps. The scalability of the process and water consume optimized can only be achieved with the planning and project of a dedicated plant for production scale. The characteristics of the Zircaloy 4 scraps electrode indicate that it is adequate for the melting in the laboratory VAR furnace.

\section{Acknowledgement}
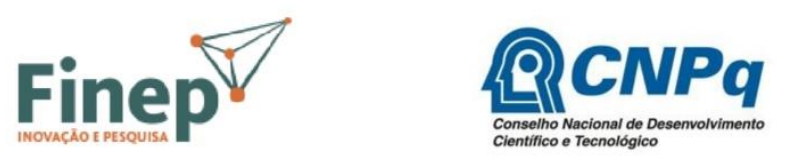

\section{References}

[1] Zirconium Alloy, United States. Disponível em <https://en.wikipedia.org/wiki/Zirconium_alloy>. Acesso em: 27 Mai. 2016

[2] MUCSI, C. S. Estudo sobre o processo V.A.R. (Vacuum Arc Remelting) escala e laboratório. Dissertação (Mestrado em Reatores Nucleares de Potência e Tecnologia do Combustível Nuclear), Instituto de Pesquisas Energéticas e Nucleares, Universidade de São Paulo, São Pulo, 1996.

[3] Combustível Nuclear, Rio de Janeiro. $<$ http://www.inb.gov.br/pt-

br/WebForms/interna2.aspx?secao_id=105>. Acesso em 27 Mai. 2016.

[4] SATO, I M.; PEREIRA, L. A. T.; SCAPIN, M. A.; COTRIM, M. B.; MUCSI, C. S.; ROSSI, J. L.; MARTINEZ, L. G. Journal of Radioanalytical and Nuclear Chemistry, v. 294, n. 2, p. 283-288, 2012.

[5] MUCSI, C.S.;FARIA, R.N.; GALEGO, E.; ROSSI, J.L. Materials Science Forum, v. 498/499, p. 258-263, 2005.

[6] MUCSI, C. S. Proposição de um processo alternativo à fusão via forno VAR para a consolidação de cavacos prensados de Zircaloy e estudo do sistema dinâmico do arco elétrico. Tese (Doutorado em Tecnologia Nuclear), Programa de Pós-Graduação em Tecnologia Nuclear, Instituto de Pesquisas Energéticas e Nucleares, Universidade de São Paulo, São Paulo, 2005 